УДК 82.09

ББК $83.3(0)$
КРУГЛЫЙ СТОЛ

«ИСТОРИОГРАФИЯ ГРАЖДАНСКОЙ ВОЙНЫ В РОССИИ В ПАМЯТНИКАХ

ЛИТЕРАТУРЫ, ЭГО-ДОКУМЕНТАХ

И ПУБЛИЦИСТИКЕ»

(C) 2017 г. 3.С. Закружная

Институт мировой литературы

им. А.М. Горького Российской академии наук,

Москва, Россия

Дата поступления статьи: 25 июня 2017 г.

Дата публикации: 25 сентября 2017 г.

DOI: I0.22455/2500-4247-20I7-2-3-370-38I

Обзор подготовлен при финансовой поддержке РФФИ, грант № 17-84-01005 а(ц)

«Историография Гражданской войны в России в памятниках литературы, дневниках писателей, переписке с читателями. Исследования и публикации архивных материалов».

Информация об авторе: Зоя Сергеевна Закружная - старший научный сотрудник, Институт мировой литературы им. А.М. Горького Российской академии наук, ул. Поварская, д. 25 а, г21069 Москва, Россия.

E-mail: z.zakruzhnaya@mail.ru 


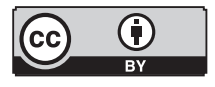

This is an open access article distributed under the Creative Commons Attribution 4.0 International (CC BY 4.0)

\section{ROUND TABLE}

"ISTORIOGRAPHY OF RUSSIAN

CIVIL WAR IN LITERATURE, EGO-DOCUMENTS AND CRITICISM"

(C) 20I7. Z.S. Zakruzhnaya

A.M. Gorky Institute of World Literature

of the Russian Academy of Sciences, Moscow, Russia Received: June 25, 2017

Date of publication: September 25, 2017

Acknowledgements: This conference summary is supported by Russian Foundation for Basic Research (RFBR), no I7-84-0I005 а(ц) "Instoriography of the Civil War in Russia as Reflected in Literature, Writers' Journals, and Their Correspondence with Readers. The Study and Publication of Archive Materials.”

Information about the author: Zoya S. Zakruzhnaya, Senior Researcher, A.M. Gorky Institute of World Literature of the Russian Academy of Sciences, Povarskaya 25 a, Moscow, Russia.

E-mail: z.zakruzhnaya@mail.ru 
6 июня 2017 г. в Институте мировой литературы им. А.М. Горького РАН состоялся круглый стол «Историография Гражданской войны в России в памятниках литературы, эго-документах и публицистике», организованный в рамках исследовательских грантов РФФИ № I7-84-0І0о5 а(ц) «Историография Гражданской войны в России в памятниках литературы, дневниках писателей, переписке с читателями. Исследования и публикации архивных материалов» (руководитель проекта - зам. директора ИМЛИ РАН, заведующая Отделом рукописей, д.ф.н. Д.С. Московская) и І7-84-0IоO2 а(ц) «Классическое произведение о Гражданской войне - “Бронепоезд I4-69” Всеволода Иванова: исторический и литературный контексты» (руководитель проекта - заведующая Отделом новейшей русской литературы и литературы русского зарубежья ИМЛИ РАН Н.В. Корниенко).

Проблематика, методологические и источниковые основания предложенных к обсуждению докладов находились на стыке научных интересов литературоведов, историков, политологов и культурологов. Однако, как подчеркнула открывшая работу круглого стола Д.С. Московская, столь же значительна их историко-литературная составляющая. Она заключается в стремлении осмыслить историко-литературный статус и социальное назначение сочинений, посвященных Гражданской войне. Д.С. Московская призвала участников попытаться сопоставить претендующую на документальность художественную «процессуальную историю» с «дневниковым летописанием», с отзывами читателей, установить, ответом на какие социальные вызовы явился тот или иной мотив или сюжет в исторической беллетристике, установить их историко-литературную перспективу - «форми- 
рование или развитие той или иной стилевой традиции художественного отображения выдающихся исторических (мифогенных) событий». В качестве примера были приведены упоминания об открытии «ревзаповедников» в самых кровавых «пунктах» Гражданской войны в полуфантастическом романе А. Платонова «Чевенгур», «геологическая катастрофа» - эвфемизм, за которым скрываются в платоновской фантастической повести «Эфирный тракт» события первых лет революции, стратегия цензурного редактирования сборника воспоминаний «Женщина в гражданской войне. Эпизоды борьбы на Северном Кавказе в І9I7-г920-х гг.» (1937), героизация белогвардейского лагеря в пьесе М. Булгакова «Дни Турбиных», крестьянская стихия партизанщины у Вс. Иванова, С. Есенина, Вяч. Шишкина, Л. Леонова, «персонализм» М. Шолохова и Ф. Крюкова, физиология войны у Б. Пильняка, И. Бабеля, Н. Никитина, «человеческая лава» («множества») у А. Серафимовича, И. Сельвинского и А. Малышкина и «кулеш социализма» у А. Платонова, кризис традиционного «гуманизма» у Б. Лавренева и А. Фадеева, стилевое и содержательное использования «документа» эпохи Гражданской войны у Д. Фурманова, Вс. Вишневского и А. Толстого. Все это и многое другое очерчивает, по словам докладчика, перспективы изучения новых художественно-идеологических тенденций в текстах о Гражданской войне советского и «антисоветского», «белого» и «красного», ушедшего в эмиграцию и осевшего в метрополии русского XX и XXI вв. Этими общетеоретическими и историко-литературными аспектами, как подчеркнула Д.С. Московская, не исчерпывается историко-литературная проблематика круглого стола. Важнейшей ее составляющей является неисследованность архивных фондов личного происхождения и литературных организаций, содержащих редакции и варианты произведений о Гражданской войне, Д. Фурманова, Э. Багрицкого, Демьяна Бедного, Алексея Толстого, А. Малышкина, Б. Пильняка, Артема Веселого, А. Серафимовича и др., дневников этих писателей, отзывов читателей на произведения о Гражданской войне, дискуссии о произведениях о Гражданской войне в ЛОКАФе (Литературное объединение Красной армии и флота), РАППе (Российской ассоциации пролетарских писателей), ВОКПе (Всероссийском объединении крестьянских писателей), Всеросскомдраме (Всероссийском объединении композиторов и драматургов). Неизученность этих документов является очевидной историко-литературной лакуной, требующей заполнения. Докладчик при- 
звала участников обратить внимание на гендерные особенности повествования о Гражданской войне, тематические и поэтологические аспекты ее изображения в документальных и литературных жанрах, на идеологемы, риторические стратегии и ракурсы интерпретации, уточнение творческих биографий писателей, историй их произведений, выявление отзывов на них современников, определение места этих текстов в историко-литературном процессе времени.

Гендерному аспекту - взгляду женщин на события Гражданской войны - было посвящено сразу несколько докладов. Первый из них - доклад докторанта Литературного института им. А.М. Горького, Астащенко Елены Васильевны «“За все благодарите”: проблема милости и справедливости в женской прозе о Гражданской войне», в котором рассматривалась «документальная» женская проза о революции, принадлежащая перу не только писательниц (В. Жуковской, А. Даманской), но и медицинских сестер (В. Шелепиной), офицерских жен и дочерей (М. Сливинской, Н. Щербачевой, А. Линден). Докладчик сосредоточился на нравственном аспекте рассматриваемых текстов, на нравственных установках и оценках женщинами Гражданской войны, и утверждал, что в этой прозе ценно именно то, что «выражено исподволь» - милосердие, даже к врагу. Докладчик считает, что «трогательная самонадеянность элиты, неразрывная с упованием на их Бога (официально большевиками отвергнутого), выдает белогвардейское присвоение прерогативы на истину», но, согласно поставленной авторами произведений задаче - «написать точно, верно, правдиво, как всё было, без всяких преувеличений» (В. Шелепина), «почти стенограмму» (В. Жуковская), женщины, «вопреки своей природе», избегали оценочных эпитетов, эмоционально-экспрессивной или инвективной лексики. И потому особенно ценно, считает докладчик, что сострадание, а иногда и уважение к идейным противникам исподволь высказывается в элементах самого повествования, рассмотрение которых и стало центром доклада Е.В. Астащенко.

«Женской прозе» о Гражданской войне был посвящен и доклад Татьяны Вячеславовны Марченко, д.ф.н., заведующей отделом культуры Российского Зарубежья Дома русского зарубежья им. А. Солженицына «“Брак в красном вихре” Али Рахмановой: немецкий роман русской писательницы о Гражданской войне в России», предметом рассмотрения в котором явились романы из дневниковой трилогии («Студенты, любовь, ЧК и смерть», 
I931, и «Брак в красном вихре», І932) малоизвестной в России, но весьма популярной за рубежом писательницы Али Рахмановой (настоящее имя Галина Дюрягина, в замужестве - фон Хойер) о событиях Гражданской войны, свидетелем которой она была. Изучение дневников писательницы (чье наследие хранится в государственном архиве кантона Тургау, Фрауэнфельд, Швейцария) и ее романов дает возможность, как полагает докладчик, коснуться проблемы соотношения эго-документа и художественного вымысла и расширить представления о рецепции западноевропейским сознанием русской послереволюционной смуты.

Еще один «женский взгляд» на события Гражданской войны был представлен в докладе Ольги Алексеевны Симоновой, с.н.с. Отдела рукописей ИМЛИ РАН, «Воспоминания А.А. Саксаганской о Гражданской войне (махновцы в Екатеринославе)», который был посвящен хранящимся в Архиве Горького двум воспоминаниям писательницы о Гражданской войне («В тылу», «Под черным флагом»), написанным в конце г920-х гг., но неопубликованным. Как сообщил докладчик, воспоминания «Под черным флагом» посвящены описанию деятельности Нестора Махно и его отряда в Екатеринославе в І9І9 г., а воспоминания «В тылу» представляют собой зарисовки жизни при разных режимах в Гражданскую войну, когда «писательница, как женщина, еврейка и богатая домовладелица, оказалась в особо уязвимом положении». Тексты, по мнению докладчика, существенно расширяют наши представления о военной тактике Нестора Махно и нравах времен Гражданской войны.

Документы, связанные с таким историческим лицом, как Нестор Махно, также оказались в центре внимания Галины Николаевны Воронцовой, с.н.с. Отдела новейшей русской литературы и литературы русского зарубежья ИМЛИ РАН, в ее докладе «Документы и материалы о Несторе Махно и “махновщине” в фонде А.Н. Толстого ОР ИМЛИ РАН». Докладчик сообщил, что в фонде А.Н. Толстого в ОР ИМЛИ сохранился комплекс материалов, которыми пользовался писатель при создании образа Нестора Махно в трилогии «Хождение по мукам». К таковым относятся книга И. Теппера (Гордеева) «Махно. От единого анархизма к стопам румынского короля» (1924) с многочисленными подчеркиваниями Толстого, выписки из «Дневника жены Махно», письмо С.Ф. Буданцева Толстому от 26 апреля 1928 г. из Днепропетровска (Екатеринослава) с подробностями взятия 
города армией Махно в конце I9I8 г., а также Акт о расстреле махновцами атамана Григорьева, подписанный самим Махно и людьми из ближайшего его окружения. Анализ этих документов, по мнению докладчика, позволяет не только расширить круг источников романа, но и уточнить целый ряд существенных моментов его творческой истории.

А.Н. Толстой стал одним из главных героев и другого доклада Юрия Николаевича Кирьянова, с.н.с. Отдела новейшей русской литературы и литературы русского зарубежья ИМЛИ РАН, - «Архивные материалы (воспоминания, беседы, письма участников гражданской войны) и повесть А.Н. Толстого “Хлеб”, посвященного стенограмме беседы Толстого с активным участником гражданской войны на юге России Е.А. Щаденко (РГАСПИ. Ф. 7І. ОП. № 35. Ед. хр. 905). По мнению докладчика, «неизвестные события и факты, человеческие судьбы, о которых идет речь в рассказе Щаденко, помогают понять причины и неизбежное нарастание революционного взрыва, показывают насколько была глубоко поражена острыми социальными и этническими конфликтами жизнь России того времени». Докладчик утверждал, что «сопоставление архивных документов с повестью “Хлеб” выявляет принципы отбора событий и эпизодов подачи их в произведении, показывает, как повесть вносила свой вклад в конструирование новой реальности в стране».

Проблема рецепции Гражданской войны в художественных произведениях последующих десятилетий поднималась также в докладе Елены Алексеевны Папковой, с.н.с. Отдела новейшей русской литературы и литературы русского зарубежья ИМЛИ РАН, «“Союзники” и Россия в период Гражданской войны: на материале сибирской периодики I9I9 г. (неизвестные материалы из газеты “Вперед!”) и “Бронепоезда І4-69” Всеволода Иванова». Докладчик рассматривал различные точки зрения на проблему взаимоотношений России и «союзников» в период Гражданской войны и сообщил, что важный для истории Гражданской войны вопрос об отношениях России и союзных держав: Франции, Америки, Японии - в неизвестной ранее публикации Вс.В. Иванова «Узы дружбы» (Вперед. Омск, І9І9. 26 сент.) решался «в общем ключе понимания его русской интеллигенцией, участвовавшей в Первой мировой войне: “союзники” и Россия, в отличие от прогермански настроенных коммунистов, защищают подлинно демократические интересы свободы и равенства людей». 
Другую сторону вопроса, по сообщению докладчика, демонстрируют публикации газеты «Вперед», посвященные «заговору во Владивостоке» эсеров, большевиков и «союзников» против законного Российского Правительства А.В. Колчака (I9I9. I7 окт.), а именно выражают опасение за национальные интересы России, которым угрожают двойственно ведущие себя «союзники».

Это противоречивое отношение русской интеллигенции к роли «союзников» в Гражданской войне, как считает Е.А. Папкова, нашло отражение в «Бронепоезде І4-69» Вс.В. Иванова (повести г92г г., пьесе 1927 г. и сценарии г963 г.), определив трактовку писателем центральных образов.

Одним из центральных проектов, связанных с восприятием и воссозданием (и пересозданием) истории Гражданской войны в г930-е и последующие годы, охватившем как историческую науку, политику и идеологию, так и литературное творчество, стал проект М. Горького, которому был посвящен доклад Ольги Васильевны Быстровой, с.н.с. Отдела издания и изучения творчества М. Горького ИМЛИ РАН, «Издательский проект М. Горького “История Гражданской войны”: По материалам РГАСПИ».

Предметом исследования докладчика стала книгоиздательская серия «История Гражданской войны», задуманная М. Горьким. Исследование вопроса, как показала О.В. Быстрова, позволяет увидеть само движение замысла І6-томной серии, который воплотился лишь в пяти книгах, посвященных трагическим годам Гражданской войны в СССР. Задуманная как серия научно-популярных книг для крестьянства, она превратилась в центр, объединяющий историков, политиков и писателей. Найденные докладчиком в РГАСПИ письма Горького, вводимые в научный оборот, позволяют осознать не только грандиозность замысла, но и увидеть «каждодневный труд ответственного редактора серии, каковым и являлся М.А. Пешков (Горький)».

Замысел проекта М. Горького вызвал новую волну интереса к теме Гражданской войны среди литераторов и критиков, о чем можно судить по докладу Зои Сергеевны Закружной, с.н.с. Отдела рукописей ИМЛИ РАН, «Принципы изображения героя гражданской войны в критических выступлениях членов ЛОКАФ (по материалам архива ОР ИМЛИ РАН)». Предметом рассмотрения 3.С. Закружной явился доклад Л.М. Субоцкого, одного из ведущих критиков ЛОКАФ, на Втором расширенном пленуме объединения. 
Доклад критика был посвящен принципам изображения героя Гражданской войны в художественной литературе. По мнению докладчика, можно предположить, что возобновление интереса критиков ЛОКАФ к Гражданской войне связано с проектом Горького и с вышедшими в июле-августе г93I г. постановлениями о издании «Истории Гражданской войны». 3.С. Закружная сообщила, что в докладе критика прозвучали теоретические положения о том, каким, согласно требованию времени (I932), должен быть представлен герой Гражданской войны в «литературной продукции» ЛОКАФ. Доклад критика позволяет увидеть не только то, как воспринималась Гражданская война ее непосредственными участниками десятилетие спустя, но и то, какие идеологические установки в отображении Гражданской войны превалировали в 1932 г., и то, какое именно воспитательное / идеологическое значение придавалось изображению Гражданской войны в контексте уже совсем иной эпохи.

На материале архивов литературных организаций ОР ИМЛИ РАН был основан и доклад Александра Александровича Гончаренко, аспиранта Отдела рукописей ИМЛИ РАН, «Обсуждение фильма “Чапаев” 29 ноября I934 г.: правда и вымысел в воспоминаниях очевидцев и создателей». В своем выступлении докладчик освещал неопубликованный документ - «Обсуждение фильма “Чапаев” , - выявленный в фонде Всероскомдрам (ОР ИМЛИ. Ф. 52. Оп. І. Д. 220. 78 Л.). По сообщению докладчика, дело содержит стенограмму выступлений деятелей культуры и участников Гражданской войны, состоявшихся в Доме советского писателя 29 ноября І934 г. Сфокусироваться на конкретном обсуждении докладчика заставляет следующая особенность документа: «...в тот вечер состав гостей отразил весь спектр публики». Выступали и соратники Чапаева (военные Васканов, И. Кутяков, Петроковский, М. Попова), и свидетели различной степени вовлеченности (писатель Бедный и военный Эйдеман), и создатели фильма (кинематографисты Васильевы и Мясникова), и представители «литературного истеблишмента» (литераторы Киршон и Сурков). И все выступавшие, по сообщению А.А. Гончаренко, встретили фильм восторженно. По словам докладчика, «эта пестрота бэкграундов выявляет общую линию, которой велось прославление фильма и актуализация на его материале большевистских идеологем».

О возросшем интересе к теме Гражданской войны в связи с замыслом М. Горького можно судить также по докладу Максима Львовича Федорова, 
с.н.с. Отдела рукописей ИМЛИ РАН, «Демьян Бедный и Гражданская война (по материалам ОР ИМЛИ РАН)», в котором рассматривались два текста участников Гражданской войны, присланные Демьяну Бедному, чье имя, по сообщению докладчика, в период Гражданской войны среди красноармейцев становится нарицательным, его агитками зачитываются, их ждут и заучивают наизусть; «в это время поэт много ездит по фронтам, в собственном, подаренном ему партией, вагоне, читает солдатам свои агитки». Первый текст - воспоминания М.М. Макарова (О Гражданской войне г9г9 г.) представляет, по мнению докладчика, интерес, поскольку автор был непосредственным участником описываемых событий - нескольких дней, проведенных им в белогвардейском плену. Как сообщил докладчик, лишенный откровенно выраженной большевистской идеологии, текст обнаруживает глубинные, христианские в своей основе ценностные позиции автора. Докладчик отмечал удивительность того, что автор не побоялся высказать их в начале г930-х гг., предназначив свой текст для горьковского проекта «История Гражданской войны», также докладчик отметил особенности поэтики текста, которые дают возможность, по мнению М.Л. Федорова, сравнивать его со знаменитым рассказом В.М. Гаршина «Четыре дня».

Второй текст - «Очерк финляндской революции г9г8 г. и взаимоотношений между Финляндией и Россией» И.А. Киреева, - по мнению докладчика, интересен тем, что написан по горячим следам описываемых событий и посвящен одной из самых малоизученных страниц Гражданской войны - событиям в независимой Финляндии. Как сообщил докладчик, текст наполнен переведенными автором с финского языка цитатами из прессы тех лет. Интерес представляет и фигура самого автора. На основании предварительных разысканий М.Л. Федорова стало понятно, что Иван Алексеевич Киреев - известный русский гидрограф, доктор военно-морских наук, автор многочисленных исследований, посвященных гидрографии. Объемный труд, посвященный истории Гражданской войны в Финляндии, - единственный опыт обращения ученого к гуманитарным наукам.

Важный вклад в уточнение событий Гражданской войны и роли отдельных личностей в ней вносит и доклад Ирины Глебовны Страховской, профессора кафедры славяноведения и культурологии РГУ им. А.Н. Косыгина (Институт славянской культуры), «Гражданская война в России: Орден “За Великий Сибирский поход”». Сбор, сопоставление и анализ новых 
материалов из различных источников, в том числе из семейного архива, дали возможность докладчику узнать и понять роль полковника Генштаба Ивана Ивановича Попова, І888 г. рождения, уроженца Якутска, в Великом Сибирском Ледяном походе. Докладчику стало известно не только то, что полковник Попов был назначен начальником штаба Северной колонны, которая смогла преодолеть самый тяжелый отрезок пути отступления, сохранив свою боевую организацию, но и то, что он был награжден Знаком отличия Военного ордена «За Великий Сибирский поход». Удалось узнать и о его наградах, полученных в Первой мировой войне, и о том, что «после иммиграции он был назначен Начальником Австралийского Отделения РОВС, идейная позиция которого наиболее полно изложена в трудах философа И.А. Ильина».

Необычные взгляды на события Гражданской войны были представлены в докладах Марины Альбиновны Ариас-Вихиль и Ларисы Григорьевны Жуховицкой.

Так, в докладе Марины Альбиновны Ариас-Вихиль, с.н.с. ИМЛИ РАН, «Герои Гражданской войны глазами Луи Арагона (В. Примаков, M. Тухачевский)» был представлен взгляд на события Гражданской войны иностранца, известного французского поэта и писателя Луи Арагона, в чьих воспоминаниях рассказывается о встречах с героями Гражданской войны Виталием Примаковым и Михаилом Тухачевским. Как сообщил докладчик, их рассказы о событиях Гражданской войны и политические пристрастия оказываются в центре внимания французского писателя, гостившего в доме Примакова, женой которого была Лиля Брик, сестра Эльзы Триоле, спутницы Арагона. Эти уникальные воспоминания, по мнению докладчика, «воссоздают не только эпизоды Гражданской войны, рассказанные их участниками, но и настроения и заботы последнего лета жизни Примакова и Тухачевского, над которыми уже сгущались тучи фабриковавшегося в Кремле дела об их измене родине».

В докладе же Ларисы Григорьевны Жуховицкой, сотрудника архива М. Горького ИМЛИ РАН, события Гражданской войны представлены в воспоминаниях «лишенцев» (лиц, лишенных избирательного права, заключенных, ссыльных). Докладчик сообщил о неисследованной части корреспонденции A.M. Горького І930-х гг., часть которой и составляют письма «лишенцев». Многие из них - участники Гражданской войны, - обращаясь 
к Горькому за помощью, вспоминают (как часть своей биографии) ее события. Именно эти воспоминания и оказались в центре внимания Л.Г. Жуховицкой, что добавляет еще одну неожиданную точку зрения на события Гражданской войны.

Подводя итоги круглого стола, член-корреспондент РАН, д.ф.н., заведующая Отделом новейшей русской литературы и литературы русского зарубежья ИМЛИ РАН Н.В. Корниенко отметила важность прошедшего обсуждения: события Гражданской войны и революции, подчеркнула она, изменили ход русского литературного процесса.

Одним из возможных дальнейших направлений работы Н.В. Корниенко указала переход от литературы г920-І930-х гг. к рассмотрению литературы 1950-І960-х гг., которая предоставляет совсем иной взгляд на события революции и Гражданской войны.

Можно ожидать, что итогом работы над проектами, посвященными отражению событий Гражданской войны в литературе I920-I930-х гг., станет издание материалов по теме исследования и публикация новых архивных материалов, которые будут способствовать выработке современного отношения к событиям Гражданской войны и пополнению информации о историко-литературном процессе XX в. 